\title{
A shattered kidney: a pitfall in imaging of renal trauma
}

\author{
Cheng Fang, Mohammad Ali Husainy, Dean Huang
}

Department of Radiology, Kings College Hospital, London, UK

\section{Correspondence to}

Dr Cheng Fang,

chengfang@nhs.net

Accepted 8 October 2015

CrossMark

To cite: Fang $C$,

Husainy MA, Huang D. BMJ

Case Rep Published online:

[please include Day Month

Year] doi:10.1136/bcr-2015-

211496

\section{DESCRIPTION}

A young man fell off a bike and landed on his right side, resulting in severe right flank tenderness. A dipstick test revealed the presence of blood $(++)$, protein $(++)$ and ketones $(++)$ in his urine. Contrast-enhanced CT imaging revealed a complex right renal injury. On axial images, the devascularised lower renal pole fragment could not be easily appreciated as it was surrounded by a haematoma/urinoma; but this was better appreciated on reformatted images.

CT is the primary modality for assessing renal trauma as the severity of the haematuria is poorly correlated with the severity of the renal injury. On CT scan, the devascularised, non-enhancing renal segments in this case were not readily identified as they were surrounded and displaced by haematoma/ urinoma (figures 1 and 2). Multiplanar reformatted images improved demonstration of the unenhanced polar segments of the injured kidney (figures 3 and 4). In addition, presence of the renal sinus fat within the urinoma/haematoma aided in the identification of unenhanced renal tissue (figure 4). Together they helped alleviate the potential pitfall in this under-staging renal trauma.

The use of multiplanar CT scan often facilitates the decision between conservative and surgical management. In grade $\mathrm{V}$ injuries, where renal laceration extends through the renal cortex, medulla and collecting system, or where it involves the renal vascular pedicles, nephrectomy is often required..$^{1-3}$ However, importantly, therapeutic strategies should also be guided by the clinical picture in conjunction with functional imaging such as renal scintigraphy. This patient was successfully managed

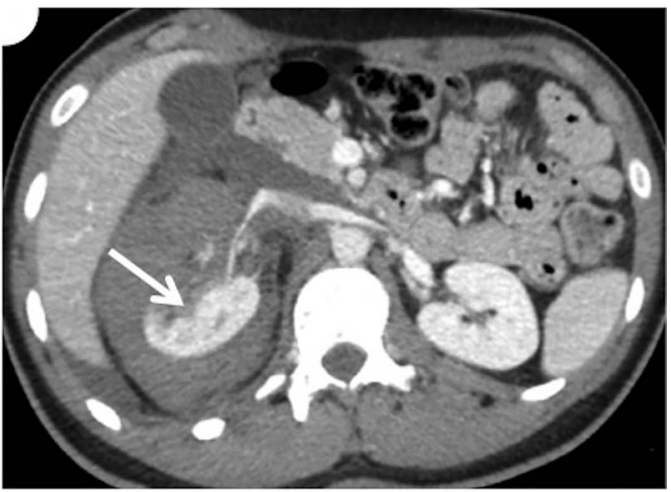

Figure 1 Right side grade $\mathrm{V}$ renal injury in axial plane. The upper pole (short white arrow) demonstrating contrast enhancement.

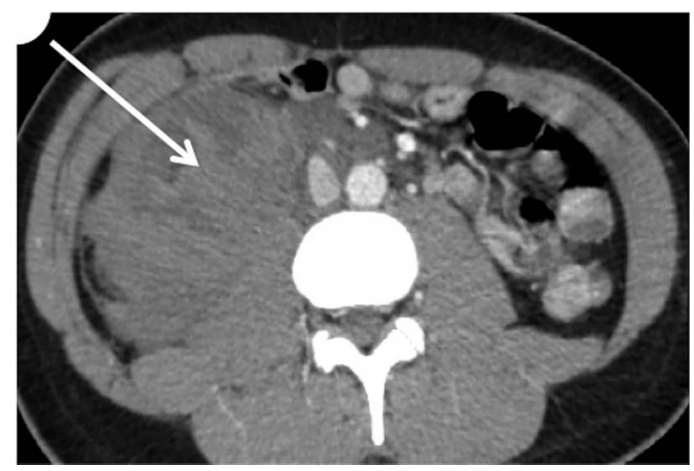

Figure 2 Right side grade $\mathrm{V}$ renal injury in axial plane. Non-enhancing lower pole renal parenchyma (long white arrow). This is completely separated from the upper pole by the haematoma/urinoma.

conservatively with eventual reduced, but valuable, right renal function (split function of 34\%) and a normal estimated glomerular filtration rate.

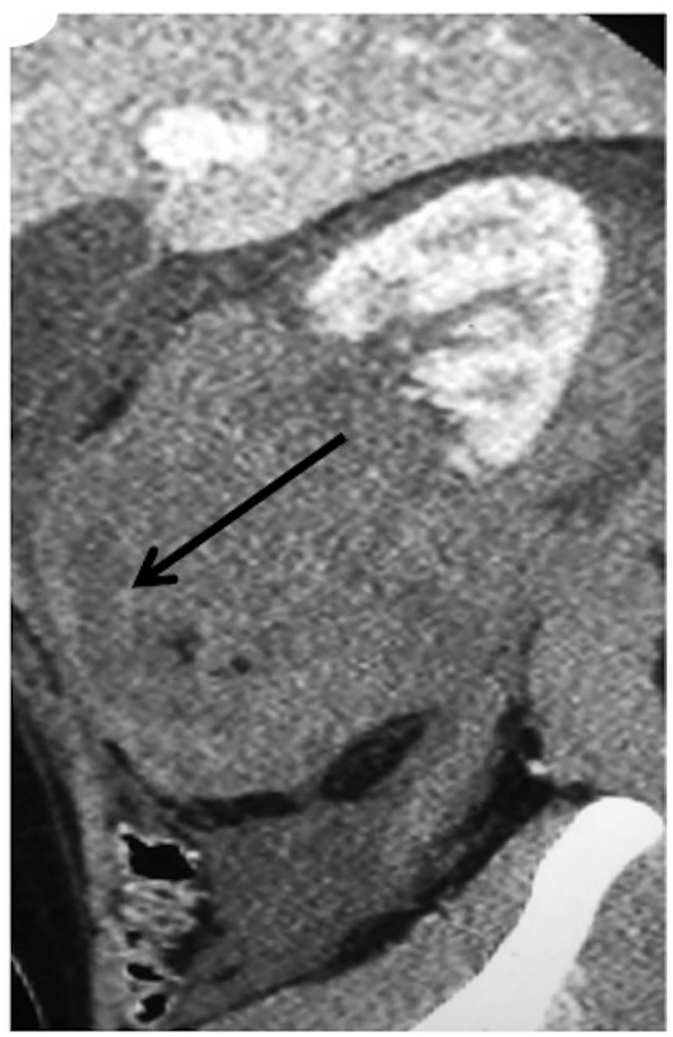

Figure 3 Right side grade $\mathrm{V}$ renal injury in sagittal plane. On these images, the devascularised lower pole cortex of the kidney is much more easily appreciated. 


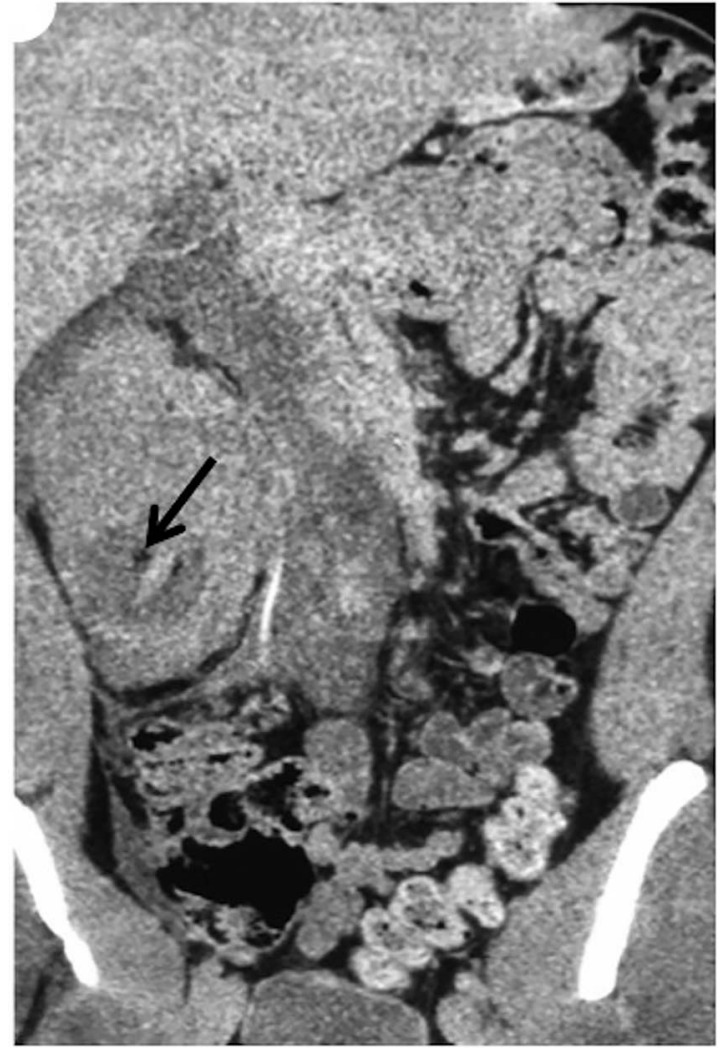

Figure 4 Right side grade $V$ renal injury in coronal plane. On these images, the devascularised lower pole cortex of the kidney is much more easily appreciated. The short black arrow identifies the fat within the separated renal pole. The intact left kidney has a normal appearance.

\section{Learning points}

- Microscopic haematuria in blunt trauma in a symptomatic patient requires further investigation with contrast-enhanced CT.

- Multiplanar reformatted images and a careful search for renal sinus fat within the haematoma/urinoma will improve accuracy of identification of devascularised renal fragments.

- Accurate assessment of the severity of the renal injury in conjunction with other clinical findings plays a key role in selecting patients for operative treatment.

Contributors All the authors actively participated in the diagnostic imaging of this patient and were involved in the preparation, editing and finalisation of the manuscript.

Competing interests None declared.

Patient consent Obtained.

Provenance and peer review Not commissioned; externally peer reviewed.

\section{REFERENCES}

1 Harris AC, Zwirewich CV, Lyburn ID, et al. CT findings in blunt renal trauma. Radiographics 2001;21:S201-14.

2 Kawashima A, Sandler CM, Corl FM, et al. Imaging of renal trauma: a comprehensive review. Radiographics 2001;21:557-74.

3 Alonso RC, Nacenta SB, Marinez PD, et al. Kidney in danger: CT findings of blunt and penetrating renal trauma. Radiographics 2009;29:2033-53.

Copyright 2015 BMJ Publishing Group. All rights reserved. For permission to reuse any of this content visit http://group.bmj.com/group/rights-licensing/permissions.

BMJ Case Report Fellows may re-use this article for personal use and teaching without any further permission.

Become a Fellow of BMJ Case Reports today and you can:

- Submit as many cases as you like

- Enjoy fast sympathetic peer review and rapid publication of accepted articles

- Access all the published articles

- Re-use any of the published material for personal use and teaching without further permission

For information on Institutional Fellowships contact consortiasales@bmjgroup.com

Visit casereports.bmj.com for more articles like this and to become a Fellow 